\title{
THE TOP-HAT IN SOUTH AFRICAN HISTORY: THE CHANGING SIGNIFICANCE OF AN ARTICLE OF MATERIAL CULTURE.
}

\section{Robert Ross}

Articles of apparel may carry strong symbolic meanings and convey messages such as gender and social status. As with other media of communication, items of dress are systematically related to each other to form codes. The top hat is a good example. Part of the urban uniform of the English male upper class from the late eighteenth century onwards, the top hat had become unfashionable in elite circles by the later years of the nineteenth century. However, by this time, the top hat had been adopted as part of the regalia of political leaders outside the colony and in later years, of the South African State President and of participants in the licenced saturnalia of the Coon Carnival.

Until 1961 the parliament of what was still the Union of South Africa was opened annually by the Governor-General. On these occasions, he was dressed in the full panoply of a British colonial governor, complete with tropical whites, the insignia of the Order of those holy dragon slayers, Saints Michael and George, and a cocked hat and ostrich feathers. Throughout the British Empire and Commonwealth the same symbols of authority were in use, and in their exoticism they stressed the diminishing unity of that somewhat nebulous entity. Since then this ceremonial function has been taken over by the State President of the Republic. His official dress is somewhat more sober. He wears a long black frock coat and a sash in the official colours of the Republic, and on his head, or more frequently in his hand, is a large, shiny black top hat. It is on the history of this last piece of paraphernalia that I wish to concentrate on in this paper.

The top hat, and indeed much of the rest of the President's costume, is very evidently ritualistic. In general, white men have given up wearing hats in town - certainly they are not part of general fashionable dress - and even were this not the case, the top hat is neither the most comfortable nor the most practical of headgear. In addition to the opening of Parliament, top hats are only likely to be seen in South Africa during Cape Town's Coon Carnival, though then they are not black silk, but coloured in the livery of the various troups and bedecked with ribbons. They are reserved for the apogee of the official hierarchy and for the country's only sanctioned Saturnalia, for the only public and admitted reversal of its order. Their symbolic function seems evident, although in the latter case the headgear also harks back to that of the Afro-American Jubilee singers led by O.M. McAdoo, which visited South Africa in the last decade of the nineteenth century when the Coon troupes began to be organised (Chirenje, 1987; Erlmann, 1988).

It should be obvious that all articles of apparel carry strong symbolic meanings. The clothes that we wear do not only protect us against heat or 
cold, against rain or sun. Indeed it has been said that "the least siginificant motive underlying the selection and wearing of certain items of clothing is protection from the elements.' (Schwartz, 1958: 27, cited in Sahlins, 1976:183). They also make statements about ourselves, and we are more or less conscious of the statement that they are making. In general the messages which they can portray are fairly simply - this is my gender, this is the social status which I am claiming, this is the activity in which I am now engaged, or at least I am the sort of person for whom such activity is appropriate, and so on. On the other hand, these are among the most important statements which a person can make about him or herself.

Two further points have to be made by way of introduction. First, as Umberto Eco has written, the best definition of a sign is that it is something with which people can lie (Eco, 1977:6). Moreover, such lies do not have to be successful. It may be that claims to status are negated by imperfections in the outfit. There is a famous South African instance in the photograph of Sandile published in Brownlee's Reminiscences of Kafir Life and History (1977: xliii). From the ankles up he is dressed in the full regalia of a late nineteenth century gentleman, but his feet are bare. It is not surprising then, to turn the page and be confronted with a photo of his four wives in near-traditional Xhosa custom, though with their breasts covered. Against this, the lie may be transparent, and thus ironic or satiric in intent. The transvestite Moffies of Cape Town are an evident example of this, even more so than the Coon Carnival in its totality.

Secondly, as with all media of communication, the elements of clothing what Sahlins was tempted to call "vestemes", though he wisely resisted the temptation (1976:191) - at a given time and place are systematically related to each other to form codes, and indeed what might almost be called a structured discourse in themselves. They cannot be understood in isolation. What one is wearing only has significance in terms of the choice between that particular piece of apparel, or whole outfit, and some other, which was not selected, for economic reasons perhaps, but above all as a result of "taste". Taste is an image that one wants to project. It is only because the top hat was such a prominent and distinctive part of the code of clothing in South Africa that it can be used as a metonym, not just for that code itself, but indeed for a great deal of the display of social hierarchy in the Cape Colony, and far beyond it, from the early nineteenth century.

Indeed, not just in South Africa but also in North America and England, hats were long used as the major distinguishing symbol of "the formal public self," or at least as a summary for the messages conveyed by the whole outfit. As Lurie (1981:179) pointed out, the general abandonment of the wearing of hats by men (and indeed by women) shortly after World War II, coincided, in the North Atlantic world, with "a severe slackening of formal etiquette," with a much wider use of Christian names and so on. So far as I can judge, in many contexts white South Africans also loosened their etiquette towards each other, though not towards their black underlings. Nevertheless hats are still at times worn to accentuate the formality of particular occasions, above 
all, perhaps, by state ministers in their official capacity, but also by women attending church services of, notably, some of the Dutch Reformed Churches.

The top hat essentially consists of a hollow cylinder closed off by a flat crown at right angles to the body of the hat and with a narrow, not very ornate brim at the lower, head end. All parts of the construction are rigid. The hat may splay outwards on occasion, so that the crown is slightly larger in circumference than the base. In general, top hats are black, light grey toppers being reserved for so-called " morning dress", worn almost exclusively at weddings. Top hats vary between themselves primarily with regard to the height of the cylinder, which as in Uncle Sam's stovepipe could at times be excessively long, and in the material from which they were made. Initially they were made of beaver felt, but later other forms of felt and silk were used.

The top hat was apparently first manufactured in England during the 1790s. In the first decades of the nineteenth century, and certainly after the end of the Napoleonic wars, it became an essential part of the urban uniform of English male upper clases. Prints, such as Cruikshank's of the Steyne in Brighton, show how universal the top hat was among fashionable males in public.' It has been speculated that the fact that the top hat emphasises and exaggerates the height of the wearer was a reason for its popularity, as might perhaps be expected in a society where nutrition levels had led to a strong correlation between physical size and social status (Lurie, 1981:178; Floud and Wachter, 1982). ${ }^{2}$ It could also be worn in the country, notably when riding to hounds, and later in the nineteenth century by women, but again generally for riding and in a form so abbreviated that it could only be held on by pins or straps.

After the British conquest of the Cape Colony, the elite males in the urban centres of Cape Town and, from the 1820s on, Grahamstown, at least, followed the example and the fashions of the metropolis. This can only be demonstrated on the basis of iconographic evidence, but that evidence is nevertheless conclusive.

It is in the sketches of Sir Charles D'Oyly, a baronet in the service of the East India Company, that the top hat is most prominent. D'Oyly was at the Cape for rather over a year from April 1832, during which time he made a large number of sketches in pen and ink, pencil and sepia wash, 119 of which he considered worth preserving in an album, now in the Cape archives. The album was published in 1968 . He was highly accomplished in the medium, but also, to judge from his depictions of the scenery around Cape Town, rigorously naturalistic, though he did tend to scatter sleepy dogs whenever it was necessary to balance the composition. Therefore it is reasonable to assume that the inhabitants of Cape Town and its suburbs were dressed more or less

1. For a convenient example, see Trevelyan 1964:IV, 59

2. It is notable that the Report from the Governor of the Cape re children sent out by the Children's Friend Society frequently commented on the stunted growth of the British orphans sent to the Cape and apprenticed to Cape farmers. On the other hand, the cnormous size of many Afrikaners was a matter of notoriety in the nineteenth century. 
as he portrayed them. It is thus significant that all those who D'Oyly portrays as gentlemen, including a number of what are evidently self-portraits, are wearing top hats, even when engaged in such unsuitable activities as viewing a waterfall and sketching in a garden. Virtually everyone riding a horse in Cape Town has such head gear, and the hat is closely associated with a tailed coat, as opposed to the short jacket and wide brimmed soft hats worn by the rest of the free male population of Cape Town and its surrounds. The slaves were wearing conical straw hats (Figure 1).

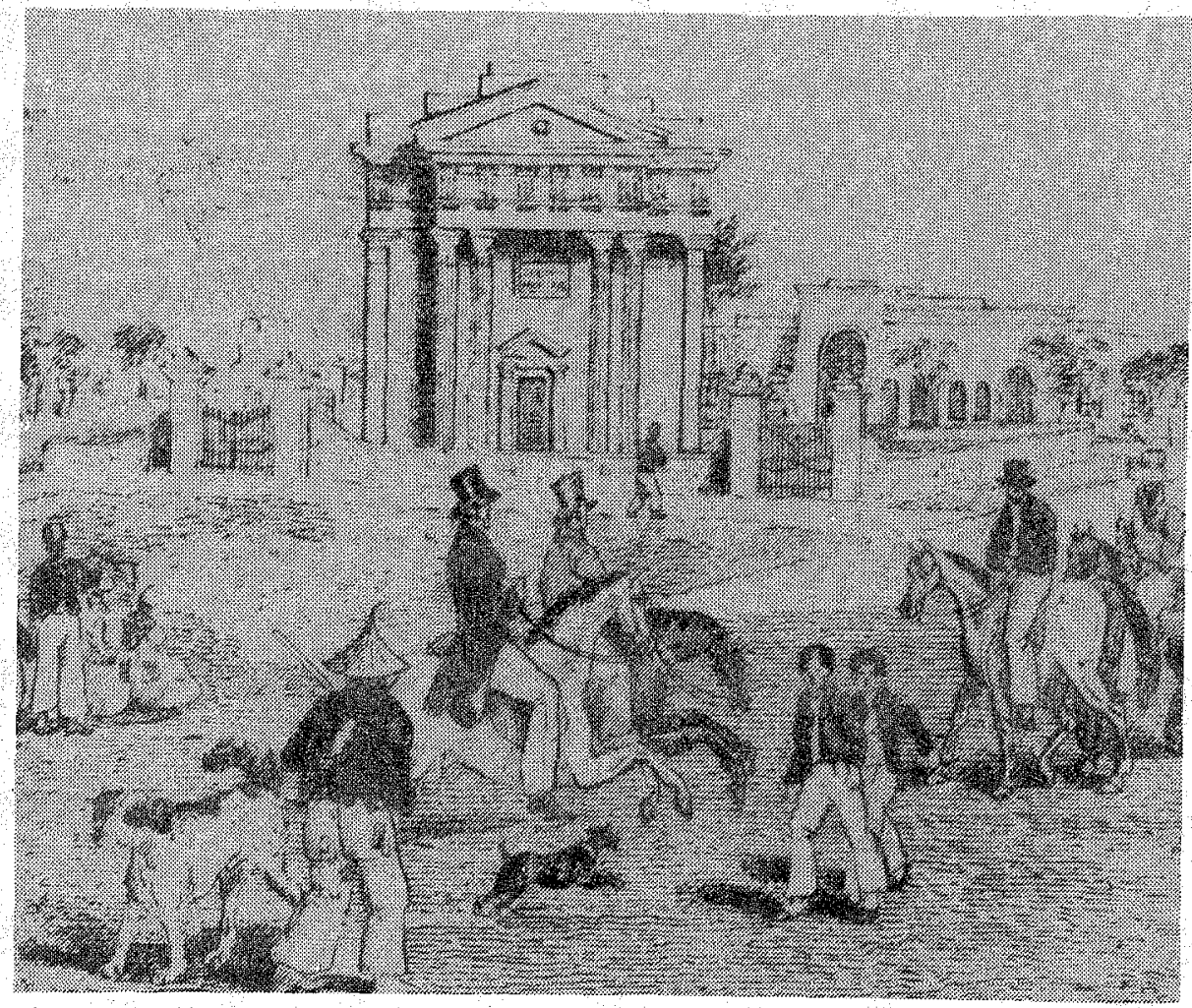

Figure 1: "View of the Scotch Kirk on the road to Greenpoint" by Sir Charles D'Oyly. April 1832.

There are two exceptions to this pattern, two men who are wearing toppers when this might not be expected. One drawing (5) shows a farmer with his ox-wagon in the streets of Cape Town. In addition to wielding his long whip, he too wears what seems to be a top hat, though the rest of his clothing is somewhat rustic. Presumably he considered that a visit to town required him to dress as befitted the more sophisticaled, urbane environment of the colony's metropolis. Secondly, there are two depictions of a man who seems to have been D'Oyly's servant wearing a topper $(13 ; 16)$. In one picture he has a 
darkened face, in the other he is on the box of a carriage outside the house which D'Oyly had rented. It would appear that D'Oyly had kitted him out in a livery which exemplified the status of the baronet who employed him (or indeed owned him - this was just before the abolition of slavery at the Cape). ${ }^{3}$

The importance of the top hat as a marker of gentility and urbanity can be further drawn from Thomas Baines's painting of Grahamstown market in 1850, held in the 1820 Settlers museum (detail reproduced in Strutt, 1975: facing p.325; also, so badly as to be almost useless, in Wilson and Thompson, 1968: facing p.242). The event Baines depicts is the return of David Hume from the interior with wagon loads of ivory, which is displayed on the ground of the market place. While the ivory is the centre of the composition, probably because there was so much of $i t,{ }^{4}$ the frieze of figures around the wagons points out very clearly the differences between the various men. In particular, there is a pair of men deep in conversation just to the left of the church. One of them, who may be presumed to be Hume himself, is wearing a brown jacket and a wide, low hat, probably colonial made. ${ }^{5}$ His companion, in clear contrast, is much more suavely dressed, and inevitably is wearing a top hat, of a model which is substantially taller than those depicted by D'Oyly two decades earlier. This distinction is repeated several times across the picture. The respectable citizens of Grahamstown were setting themselves off from the frontiersmen (and vice versa) in the most effective possible way, that is to say demonstrably and through their public personas.

By the late nineteenth century the wearing of the top hat had become somewhat restricted. Both in England and among the ruling class of South Africa it was no longer general urban wear, and by now it invariably accompanied a black coat, which might or might not be cut away, depending on the circumstances for which it was being worn. ${ }^{6}$ As a result it had come to symbolise the plutocrat, or at least the Captain of Industry, and thus be much more rarely encountered. While drawings and paintings of Cape Town and Grahamstown in the 1830 s and 1840 s contain numerous toppers, photographs of Johannesburg before and after the Boer War show few (Kallaway and Pearson, 1986). The difference cannot be ascribed entirely to the medium. The top hat had become an attribute of Hoggenheimer in cartoons, and later of the personification of apartheid? In this latter case, though, it probably derived from the top hats once worn by the leaders of the Dutch Reformed Church at synods, and reflected an association between the state and the

3. It was an eighteenth century practice for the personal servants of the rich to be dressed in a way which reflected their owners' status. See the group portrait of Captain Hendrik Storm's household, painted around 1760 and now in the Stellenbosch Museum, which is reproduced in Strutt, 1975 facing 117

4. 1850 was a bumper year for ivory exports from Southern Africa, as a result of the opening of Ngamiland. See Sheriff (1986:429).

5. By this tme hat manufacture was established n many of the small towns of the Cape Colony, almost always as the first quasi-industrial enterprise in any given location.

6. For this, see the advertisement for Henry Poole \& Co., 37 Savile Row, reprinted in Lurie (1981:168).

7. I owe this point to my student, J.B. Gewald. 
DRC, and thus their combined repression of society. The top hat was no longer the normal headgear of white elite males in real life.

In South Africa, though, there was a complication. The top hat came to be worn by the leaders of some of the political entities outside the colony. In this way they were making a claim to recognition as equal partners with the elite in the Cape Colony, and indeed with the colonial officials and governors. Perhaps the first such man to be portrayed with a top hat was Hendrik Hendriks, Secretary to the Government of the Philippolis Griquas and one of the shrewdest observers of, and participators in, the political scene of mid-nineteenth century South Africa. It was he, for instance, who when the vagrancy law was under discussion in the Cape Colony proposed that the Griquas should arrest all the Voortrekkers as vagrants, and he was a keen reader of all the

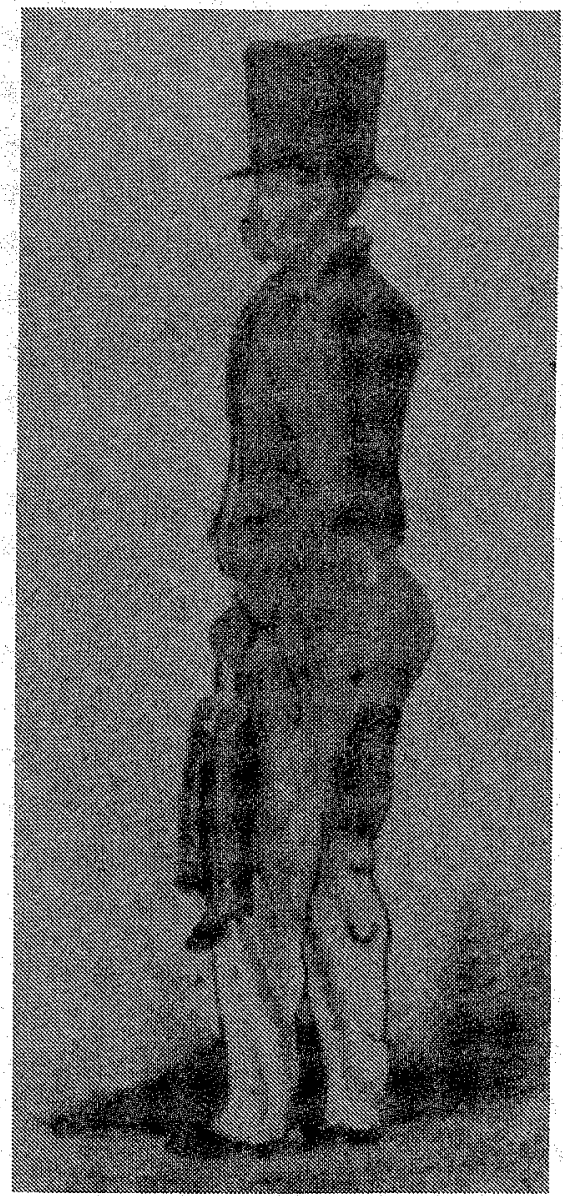

Figure 2: "Hendrik Hendriks, Secretary to the Government of Griqualand". Portrait by Charles Bell. 1834-35. 
books and newspapers he could acquire, a habit which on occasion got him into considerable trouble (Lye, 1975:141; in general, see Ross, 1976: esp. 35 6). In the summer of $1834-5$ he was drawn by Charles Bell (Figure 2) and the portrait shows very considerable ambiguity between what the artist saw and what Hendricks wished to portray. On the one hand, Bell emphasises, and no. doubt exaggerates, Hendricks's prognathous facial features and steatopygia, as if to make particularly evident that this was a man of Khoisan descent: ${ }^{8}$ On the other, Hendricks, dressed as he was in a colonial jacket, trousers, shoes and top hat, and carrying the Wellington boots he had just acquired from Dr. Andrew Smith, was doing all he could to demonstrate his superiority over the mass of the Griquas, and his equality with visitors from the Colony.

Hendricks may well have been the first extra-colonial leader to have himself portrayed wearing a top hat, but he was certainly not the last. There are two particularly striking examples of the practice during the nineteenth century. In 1860 Moshoeshoe was at Aliwal North for discussions with the Governor of the Cape Colony. On this occasion he had himself photographed wearing the full regalia of a European gentleman, including, inevitably, a black topper (Figure 3$).{ }^{9}$ He too was expressing quite clearly and demonstrably his belief in his own equality with all those with whom he had occasion to have discussions. If he had appeared at Aliwal North dressed as he had been portrayed by the French missionaries three decades earlier, in what was portrayed as Sotho traditional costume, albeit with overtones of a Roman toga, it is most doubtful whether he would have been treated with the same respect.

The other man for whom the top hat was an inevitable part of his dress, at least in his public image, was Paul Kruger. Indeed, the South Africans with whom I have discussed this paper, admittedly a tiny and hardly random sample, have all mentioned Oom Paul as the archetypical exponent of this article of dress. Kruger was faced by the same problem as Moshoeshoe, that of making himself acceptable to an international audience, and especially to a British one which had come to see the Transvaal Afrikaners as little better than the blacks over whom they ruled. For this reason he was perhaps the most consistent of all South African leaders in the nineteenth century in his wearing of a topper, though the model he sported, which had what looks like a band of fur above the brim, would not have found favour in the London of his day, where indeed the top hat was increasingly being kicked upstairs, and

8. Obviously, since 1 do not possess a photograph of Hendricks, and no doubt none was ever taken, 1 cannot judge how accurate Bell's portrait was, in the sense to which we have become accustomed since the invention of the camera. Against this, the choice of a profile for taking the portrait served to accentuate these aspects of Hendricks's appearance. In addition, such distortion in iconography is certainly not unknown. There exist's a portrait of Adam Kok III, published in the Illustrated London News (though unfortunately 1 have been unable to locate the reference to this portrait) which depicts him with much more prognathous features than ss evident on the photos of Kok which exist, for instance in Halford (1949).

9. Incidentally, he was following Boer practice in wearing a small skull cap under his hat, either to protect it from dirt - any hat wearer knows how quickly the leather band inside the hat becomes soiled - or to ensure a better fit. The skull cap can be seen peeping out from under his hat. 
only sported on particular ceremonial occasions and in combination with a very formal outfit (Figure 4).

As the twentieth century wore on African leaders, making a press for political, and perhaps social, acceptance by the whites, still continued on occasion to wear top hats, or at least to be photographed doing so. By now, they were doing so in combination with the full court dress which had become the only acceptable accompaniment for such a hat, except at weddings, when anyway light-coloured toppers were in order (Kallaway and Pearson, 1986: plate 130). Pixley Seme, one of the founders of the South African Native National Congress wore the outfit on his return from qualifying for the bar in England (Odendaal, 1983: plate 10). He was as good a man as any in South

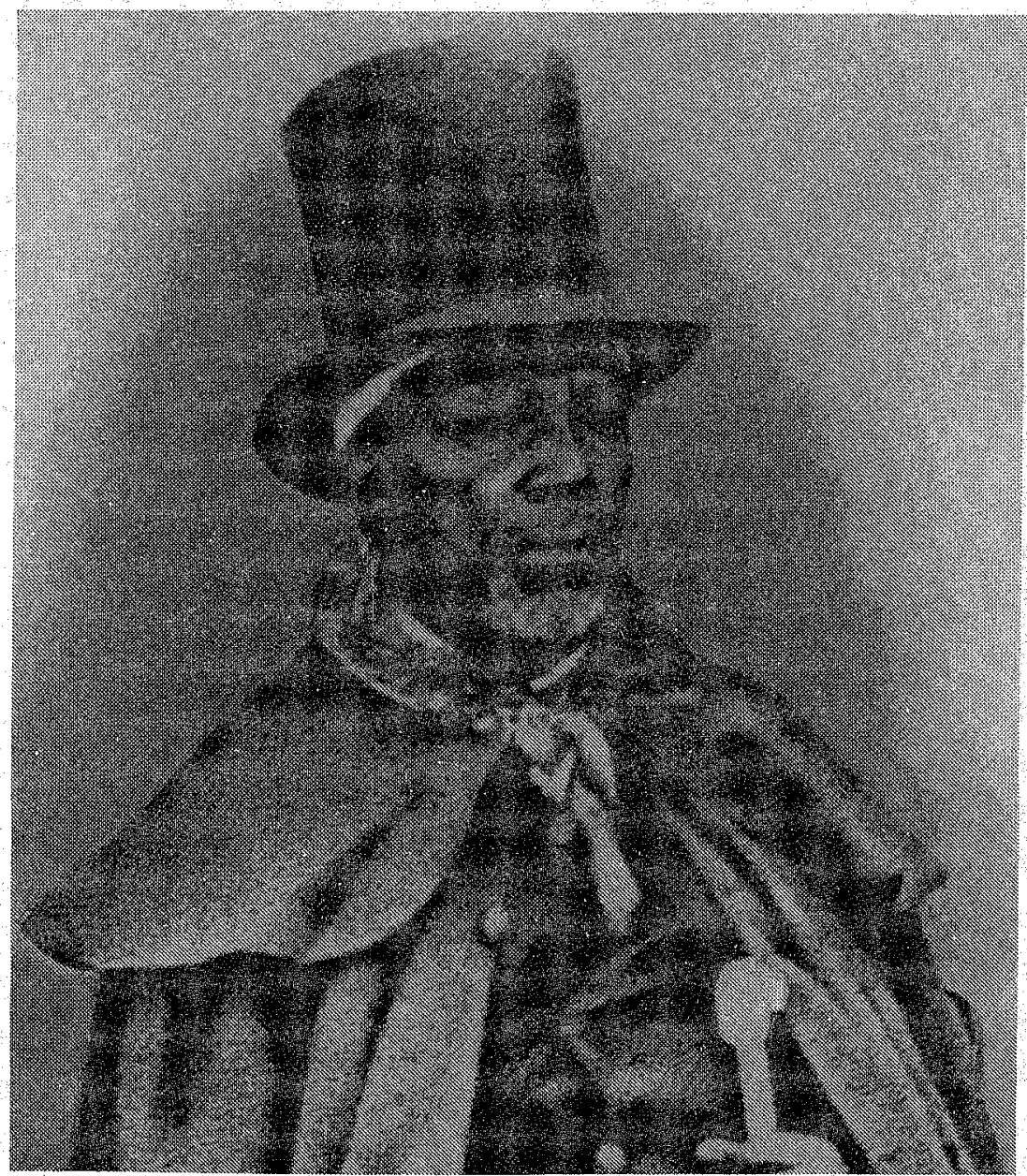

Figure 3: Moshoeshoe, photographed at Aliwal North in August, 1860. 


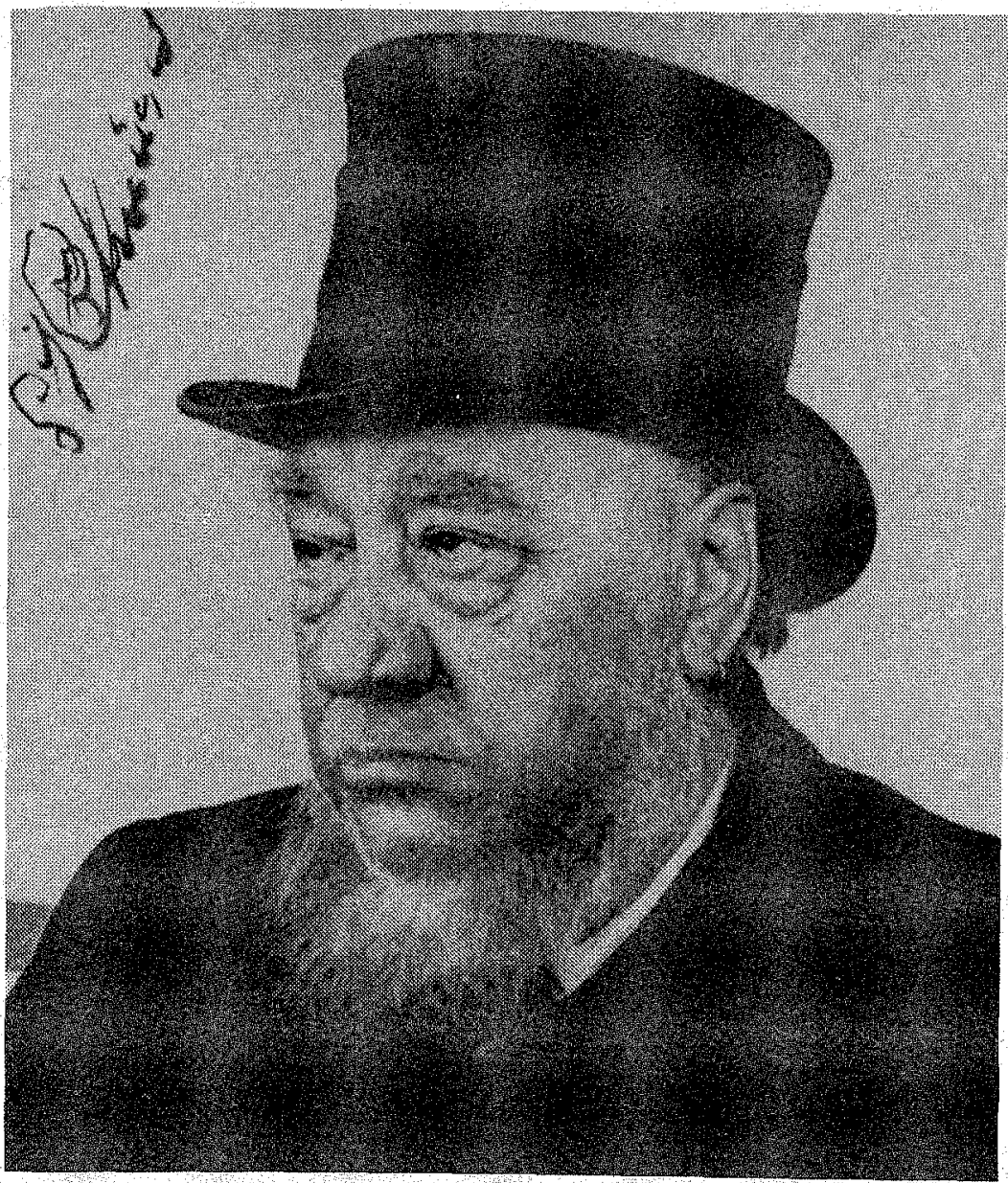

Figure 4: Paul Kruger.

Africa, he was saying, though in the event he was to be proved wrong. There is also a photograph of the Swazi royal delegation to Britain in 1923 , where again the full party is demonstrating their acquaintance with, and acceptance of, the norms of the British Empire by wearing full court dress with shiny black toppers (Willan, 1984: plate 86). The only exception in the group portrait is Sol Plaatje, who they had met in London and who had become attached to the party. He is far more soberly attired and bare-headed. Perhaps he was wanting to show his realisation that he was of a lower status than the royals, led by Sobhuza II himself, with whom he was associating, or perhaps, after several years in Britain, he was more aware of what was in fashion, and what was required.

The President of the Republic, when he ceremonially carries his black silk 
top hat, is hardly harking back to Moshoeshoe, though the icon of Paul Kruger was undoubtedly in the minds of the republicans who first devised the costume. There could be no better way to symbolize their intention of making South Africa an Afrikaner republic than by echoing the most famous image, seen for instance in the statue of Kruger in Church Square, Pretoria, of an Afrikaner republican president. In addition, though, the State president is playing his role with a formality of gesture and dress which sets him apart from the subjects of the state over which he presides. To do this, he makes use of conventions that have long ceased to be apposite to any other South Africans. He is, as it were, a sartorial fossil. But what of the Coons? Their dress has taken on a life of its own, which no longer has the satiric function it had when it was first adopted. All the same, there can be no doubt that it was in this spirit that the tradition was originated.

Rijksuniversiteit te Leiden

\section{ACKNOWLEDGEMENTS}

I would like to thank the anonymous readers for Social Dynamics for a number of very informative comments on a first draft of this article, many of which I have incorporated into this text.

\section{REFERENCES}

Brownlee, Charles Pacalt.

1977 Reminiscences of Kafir Life and History edited by Christopher Saunders, Pietermaritzburg and Durban: University of Natal Press and Killie Campbell Africana Library.

Chirenje, J. Mutero.

1987 Ethiopianism and Afro-Americans in Southerm Africa, 1883-1916. Baton Rouge and London: Louisiana State University Press.

D'Oyly, Sir Charles.

1968 The Cape Sketchbooks of Sir Charles D Oyly 1832-1833 Cape Town: Balkema.

Eco, Umberto

1977. A theory of semiotics. Bloomington and London Indiana University Press.

Erlmann, Veit.

1988 A Feeling of Prejudice Orpheus M. McAdoo and the Virginia Jubilee Singers in South Africa, 1890-1898.' Journal of Southern African Studies 14(3):331-350.

Floud, Roderick and Kenneth W. Wachter.

1982 'Poverty and Physical stature evidence on the standard of living of London boys, 1770-1870.' Social Science History 6, 4.

Halford S.J.

1949 The Griquas of Griqualand. Cape Town: Maskew Miller.

Kallaway, Peter and Patrick Peason.

1986 Johannesburg: Images and continuities: A History of Working Class Life through pictures 1885 1935. Johannesburg: Ravan.

Lye, William F. (ed.)

1975 Andrew Smith's Journal of his expedition into the interior of South Africa, 1834-6. Cape Town: Balkema. 
Lurie, Alison

1981 The language of clothes New York: Random House.

Odendaal, André

1983 Vukani Bantu! The beginnings of Black Protest Politics in South Africa to 1912. Cape Town: David Philip.

Report from the Governor of the Cape re Children sent out by the Children's Friend Society. 1840 British Parliamentary paper: 323.

Ross, Robert.

1976 Adam Kok's Griquas: a study in the development of stratification in South Africa. Cambridge: Cambridge Uniyersity Press.

Sahlins, Marshall.

1976 Culture and Practical Reason. Chicago and London. University of Chicago Press.

Schwartz, Jack

1958 Men's clothing and the Negro. MA dissertation: University of Chicago.

Sheriff, Abdul.

1986 'Ivory and Economic expansion in East Africa in the nineteenth century' in G. Liesegang, H. Pasch and A. Jones (eds.), Figuring African trade: proceedings of the symposium on the quantification and structure of the import and Export and Long Distance Trade in Africa 1800-1913. Berlin: Dietrich Reimer Verlag.

Strutt, Daphne H.

1975 Fashion in South Africa, 1652-1900. Cape Town and Rotterdam: Balkema.

Thompson, L.M.

1975 Survival in wo worlds Moshoeshoe of Lesotho. 1786-1870. Oxford: Clarendon Press.

Trevelyan, G.M.

1964 Illustrated English Social History. 4 vols. Harmondsworth: Penguin.

Willan, Brian

1984 Sol Plaatje: South African Nationalist 1876-1932. London, Ibadan and Nairobi: Heinemann.

Wilson, Monica and Leonard M. Thompson

1968 Oxford History of South Africa, Vol. I. Oxford: Clarendon Press. 